\title{
PENINGKATAN KAPASITAS MASYARAKAT DALAM KEGAWATDARURATAN WISATA PANTAI DI DESA SUMBERBENING KECAMATAN BANTUR KABUPATEN MALANG
}

\author{
Oda Debora $^{1}$, Sulistyono ${ }^{2}$ \\ 1,2Program Studi S-1 Keperawatan, STIKes Panti Waluya Malang \\ Jl. Yulius Usman no. 62 Malang, (0341) 369003 \\ e-mail: katarina29debora@gmail.com
}

\begin{abstract}
ABSTRAK
Pemerintah Kabupaten Malang saat ini sedang menggiatkan usaha dalam bidang pariwisata, terutama pariwisata pantai. Desa Sumberbening merupakan salah satu kawasan yang berada dalam jalur kawasan wisata pantai tesebut. Meskipun demikian, masih banyak penduduk yang tidak mengetahui cara memberikan pertolongan pertama pada kegawatdaruratan wisata pantai, antara lain sengatan ubur-ubur, tertusuk bulu babi, gigitan ular, dan pertolongan pada kasus tenggelam. Pengetahuan ini sangat penting untuk diketahui oleh penduduk karena lokasi pemberi layanan kesehatan sangatlah jauh sehingga pertolongan pertama jika terjadi kasus tersebut tidak dapat diberikan langsung oleh tenaga kesehatan. Dalam upaya menjamin keamanan wisatawan yang berada di lokasi pantai, seluruh pihak yang terkait, termasuk masyarakat sekitar diharapkan dapat menguasai pertolongan pertama yang harus dilakukan jika terjadi kasus tersebut. Kegiatan yang dilakukan adalah memberikan pengetahuan kepada para kader kesehatan melalui Focused Group Discussion dan workshop sederhana tentang topik tersebut. Kegiatan tersebut diikuti oleh 38 orang kader kesehatan. Kader kesehatan merasa bahwa kegiatan tersebut sangat bermanfaat karena selama ini belum pernah mendapatkan informasi tetang topik tersbut sementara kasus tersebut cukup sering ditemui. Kegiatan serupa diharapkan dapat dilakukan secara rutin agar kader semakin percaya diri dan wisatawan yang datang merasa tenang sehingga jumlah wisatawan dapat meningkat.
\end{abstract}

Kata Kunci : gigitan ular, pertolongan pertama, sengatan ubur-ubur, tenggelam, wisata pantai

\begin{abstract}
Malang Regency Government was currently intensifying tourism business, especially coastal tourism. Sumberbening Village was one of the village which was at the coastal tourism area. Eventhough, many residents who had not familiar with emergency coastal tourism first aid, including jellyfish stings, pierced sea urchins, snake bites, and drowning cases. This knowledge were very important, since healthcare facilities was far from the village and health care workers cannot performed direct assistance during the incidence. In order to ensure the tourist's safety on the beach, all parties were involved, include the health cadres were expected to master the first aid that must be done if the case occurs. The activities carried out were aimed to provide knowledge about first aid procedure through Focused Group Discussions and simple workshops for the topics. The activities were attended by 38 health cadres. Health cadres felt that the activity was very useful because so far they had never received information about the topic while the case was quite often encountered. Similar activities were expected to be carried out regularly so that cadres become more confident and tourists who come feel calm and increase visitors.
\end{abstract}

Key Words : coastal tourism, drowning, first aid, jellyfish sting, snake bite 


\section{PENDAHULUAN}

Jawa Timur merupakan salah satu Provinsi di Indonesia yang memiliki banyak potensi wisata alam. Salah satu potensi alam di Jawa Timur dan Kota Malang pada khususnya adalah wisata pantai. Wisata pantai ini merupakan salah satu penyumbang Pendapatan Asli Daerah (PAD). Wisata pantai sebagian besar dikembangkan dengan menggunakan dana desa yang telah dikucurkan oleh pemerintah. Ada beberapa daerah yang berkembang dengan sangat baik dan menjadi salah satu destinasi wisata yang sering dikunjungi. Oleh karena itu, pemerintah Provinsi bermaksud melakukan penguatan infrastruktur dalam menunjang pengembangan wilayah pariwisata baru (Setyorini, 2019).

Desa Sumberbening merupakan salah satu desa yang yang terletak di Kecamatan Bantur, Kabupaten Malang. Secara geografis, desa Pandansari terletak di wilayah Malang Selatan yang berada di Kecamatan Bantur Kabupaten Malang. Secara administratif, wilayah Desa Sumberbening terdiri dari 3 (tiga) dusun yaitu Dusun Sumberwates, Krajan dan Banjarjo. Desa Sumberbening memiliki jumlah penduduk sebanyak 5.834 jiwa yang terdiri dari 1.682 Kepala Keluarga (KK). Secara ekonomi, terdapat $332 \mathrm{KK}$ dalam kategori hampir miskin dan rumah tangga miskin sebanyak 148 KK. Daerah yang didiami oleh penduduk desa adalah daerah yang relatif datar yang sebagian berada di dataran tinggi yang ada di desa dan menyebar di jalan-jalan yang ada diseluruh wilayah desa. Akses masuk ke dalam desa Sumberbening untuk beberapa wilayah juga masih terkendala karena jalan masih makadam (Profil Desa Sumberbening, 2015).

Akses kesehatan desa

Sumberbening didapatkan dari beberapa Puskesmas Pembantu (Pustu), serta Perawat dan Bidan yang praktik. Ada 10
Pustu yang ada di desa Sumberbening, namun sarana yang dimiliki masih cukup terbatas. Hal ini akan menimbulkan permasalahan kesehatan saat masyarakat tidak mampu mencapai pusat penyedia layanan kesehatan disaat kondisi mendesak (Profil Desa Sumberbening, 2015).

Ada beberapa kasus kegawatdaruratan yang muncul terkait kondisi alam di daerah Sumberbening. Lingkungan alam yang masih penuh dengan pepohonan menjadi ekosistem yang baik bagi ular dan kalajengking. Selain itu, pada sisi pulau menjadi ekosistem bagi berbagai macam ular laut dan ubur-ubur yang akan muncul pada musim tertentu. Berdasarkan hasil wawancara yang dilakukan dengan perawat desa, dalam satu bulan terjadi kasus gigitan ular, sengatan kalajengking, atau sengatan ubur-ubur paling tidak dua hingga tiga kasus. Tidak ada pertolongan pertama yang dilakukan oleh masyarakat, dan korban langsung dibawa ke Puskesmas.

Perawat memegang peranan penting sebagai edukator dalam rangka meningkatkan kepercayaan diri dan kemampuan masyarakat dalam memberikan pertolongan pertama pada kondisi kegawatdaruratan tersebut. Pertolongan pertama yang cepat dan tepat sangat diperlukan sebagai salah satu upaya meningkatkan derajat kesehatan masyarakat dan mencegah perburukan kondisi yang meningkatkan angka morbiditas, kecacatan serta mortalitas.

\section{METODE}

Program kemitraan ini menggunakan metode penyuluhan kesehatan langsung. Subjek dalam program pengabdian masyarakat ini adalah kader kesehatan di desa Sumberbening. Kegiatan ini dilaksanakan di Balai Desa 
Sumberbening. Metode yang digunakan adalah penyuluhan dan workshop bersama tentang topik terkait. Pertemuan dilaksanakan sebanyak 3 kali dengan tema penyuluhan dan workshop yang berbeda-beda sesuai dengan kebutuhan informasi yang diperlukan masyarakat.

\section{HASIL dan PEMBAHASAN}

Ketiga kegiatan penyuluhan dan workshop dilaksanakan di Balai Desa milik Desa Sumberbening. Seluruh kegiatan dilaksanakan pada hari Sabtu dan dihadiri oleh kader kesehatan.

1. Kegiatan pertama adalah penyuluhan dan workshop tentang pertolongan pertama pada gigitan ular dihadiri oleh 32 kader kesehatan;

2. Kegiatan kedua adalah penyuluhan dan workshop tentang pertolongan pertama pada sengatan ubur-ubur yang dihadiri oleh 32 peserta;

3. Kegiatan ketiga adalah penyuluhan dan workshop tentang pertolongan pertama pada sengatan kalajengking yang dihadiri oleh 17 peserta.

Tabel 1. Alat dan Bahan Penyuluhan dan Workshop Pertolongan Pertama pada Gigitan Ular, Sengatan Ubur-ubur, dan Sengatan Kalajengking

\begin{tabular}{llc}
\hline No & \multicolumn{1}{c}{ Alat \& Bahan } & n \\
\hline 1. & LCD & 1 \\
\hline 2. & Poster & 15 \\
\hline
\end{tabular}

Berbagai kasus kegawatdaruratan trauma dan non-trauma dapat terjadi dalam kehidupan sehari-hari. Kejadian ini dapat menimbulkan injuri yang menyebabkan gangguan yang signifikan terhadap status kesehatan seseorang (Hoque et al., 2018). Oleh karena itu, kegiatan pemberian pertolongan pertama oleh awam sedang digiatkan dalam rangka membentuk komunitas yang tangguh (Wesemann, 2020). Kegiatan program kemitraan masyarakat atau pengabdian masyarakat ini selaras dengan program untuk menciptakan masyarakat yang kuat dalam bidang kesehatan. Kegiatan ini dilaksanakan melalui pemberian penyuluhan dan workshop kepada kader kesehatan.

Keterlibatan masyarakat pada prosedur pertolongan pertama kegawatdaruratan tidak akan terjadi jika tidak memiliki pengetahuan dan keterampilan. Oleh karena itu, bekal berupa pengetahuan dan pelatihan harus diberikan sebelumnya. Pengetahuan dan keterampilan yang baik akan berdampak terhadap kepercayaan diri dan keinginan untuk memberikan bantuan pada saat diperlukan (Oliver, Cooper, \& McKinney, 2014). Konsep inilah yang mendasari kegiatan penyuluhan dan workshop pertolongan pertama pada gigitan ular, sengatan ubur-ubur, dan sengatan kalajengking. Melalui kegiatan penyuluhan, masyarakat mendapat pengetahuan konseptual tentang materi yang ingin diberikan.

Pemberian materi harus disertai dengan pemilihan media pembelajaran tepat agar tujuan pembelajaran dapat tersampaikan dengan baik. Pemilihan media pembelajaran harus disesuaikan juga dengan karakteristik penerima informasi agar mendapat hasil yang maksimal. Media pembelajaran visual merupakan media yang paling umum digunakan karena dapat digunakan pada karakteristik penerima informasi secara umum tanpa kondisi khusus yang menyertai (Vieira, Parsons, \& Byrd, 2018). Pemilihan media pembelajaran pada ketiga topik ini adalah LCD untuk menampilkan PPT tentang topik yang disampaikan. Materi dalam PPT diberikan gambar yang menarik sesuai dengan topik yang diberikan agar pemahaman masyarakat juga semakin meningkat. PPT tersebut juga dijelaskan oleh pemberi materi kepada para kader. Agar ada keberlanjutan dan topik yang disampaikan dapat dibaca oleh masyarakat luas, diberikan juga poster bergambar sebagai media pembelajaran. 
Tujuan pembelajaran lainnya adalah melatih kader dalam kemampuan psikomotor agar mampu memberikan pertolongan pertama. Agar tujuan ini tercapai, maka metode pembelajaran yang digunakan juga berbeda, tidak hanya menggunakan media visual. Oleh karena itu, metode yang digunakan adalah simulasi dan dilanjutkan dengan para kader melatih kemampuannya secara mandiri. Sebuah penelitian pada para perawat pemula dan masyarakat awam menunjukkan bahwa kemampuan dan kepercayaan diri mereka meningkat setelah melakukan simulasi. Peningkatan kepercayaan diri ini memunculkan keinginan dalam diri mereka untuk memberikan bantuan saat diperlukan (Lubbers \& Rossman, 2017).

\section{KESIMPULAN DAN SARAN}

Hasil dari program kemitraan ini adalah membantu para kader dalam meningkatkan pengetahuan, kemampuan, dan kepercayaan diri kader kesehatan pada khususnya dan masyarakat pada umumnya dalam pemberian pertolongan pertama pada gigitan ular, sengatan ubur-ubur, dan sengatan kalajengking. Intervensi ini kami rekomendasikan untuk dilanjutkan oleh para kader agar dapat mengedukasi masyarakat luas. Saran bagi kegiatan kemitraan selanjutnya adalah memberikan edukasi tentang tindakan pertolongan pertama lainnya sesuai dengan kasus trauma dan non-trauma yang sering terjadi di Desa Sumberbening.

\section{UCAPAN TERIMA KASIH} kepada:

Ucapan terima kasih diberikan

1. Ketua Yayasan Pendidikan Misericordia

2. Ketua STIKes Panti Waluya Malang

3. Lurah Desa Sumberbening

4. Ketua LPPM STIKes Panti Waluya Malang

\section{DAFTAR PUSTAKA}

Hoque, D. M. E., Islam, M. I., Salam, S. S., Rahman, Q. S., Agrawal, P., Rahman, A., ... Alonge, O. (2018). Impact of First Aid on Treatment Outcomes for. A Million Person Household Survey: Understanding the Burden of Injuries in Bangladesh, 14, 78.

Lubbers, J., \& Rossman, C. (2017). Satisfaction and self-confidence with nursing clinical simulation: Novice learners, medium-fidelity, and community settings. Nurse Education Today, 48, 140-144.

Oliver, E., Cooper, J., \& McKinney, D. (2014). Can first aid training encourage individuals' propensity to act in an emergency situation? A pilot study. Emergency Medicine Journal, 31(6), 518-520.

Profil Desa Sumberbening. (2015). Retrieved from http://desasumberbening.blogspot.c om/p/profil-desa.html

Setyorini, D. A. (2019, September 25). Khofifah Beberkan Potensi Wisata di Jawa Timur. Retrieved from https://beritajatim.com/pendidikan-k esehatan/khofifah-beberkan-potensi -wisata-di-jawa-timur/

Vieira, C., Parsons, P., \& Byrd, V. (2018). Visual learning analytics of educational data: A systematic literature review and research agenda. Computers \& Education, 122, 119-135.

Wesemann, L. (2020). First Aid First: Implementation and Evaluation of a Community-based First Aid Training Course. 